\title{
COLONOSCOPY AND CARCINOEMBRYONIC ANTIGEN VARIATIONS
}

\author{
Rita G SOUSA ${ }^{1}$, Ana NUNES ${ }^{1}$, Tânia MEIRA ${ }^{1}$, Olga CARREIRA², \\ Ana M PIRES ${ }^{3}$ and João FREITAS ${ }^{1}$
}

\begin{abstract}
Context - Colonoscopy is essential for synchronous and metachronous cancer detection. Carcinoembryonic antigen is a colorectal cancer tumor marker, important as a follow-up tool in patients with previous colorectal cancer. False-positive carcinoembryonic antigen elevation results in multiples exams and in patient anxiety. In literature, there is reference to transient carcinoembryonic antigen increase with colonoscopy. Objective - To evaluate the influence of bowel preparation and colonoscopy in carcinoembryonic antigen blood levels. Methods - We prospectively studied subjects that underwent routine colonoscopy in our institution. Blood samples were collected (1) before bowel cleaning, (2) before colonoscopy and (3) immediately after colonoscopy. Blood carcinoembryonic antigen levels were determined by "Sandwich" immunoassay. The statistical methods used were the paired t-test and ANOVA. Results - Thirty-seven patients (22M/15F) were included; age range 28-84 (mean 56 years). Mean carcinoembryonic antigen values were 1.9, 2 and 1.8 for (1), (2) and (3), respectively. An increase in value (2) compared with (1) was observed in 20/37 patients $(P=0.018)$, mainly in younger patients and in patients requiring more endoluminal interventions. In $29 / 37$ patients, the CEA value decreased from (2) to (3) $(P=1.3 \times 10-7)$. Conclusions - A trend for carcinoembryonic antigen increase after bowel cleaning was observed, especially in younger patients and in patients with more endoluminal interventions, but without clinical meaning.

DESCRITORES - Colonoscopy, methods. Carcinoembryonic antigen. Colorectal neoplasms.
\end{abstract}

\section{INTRODUCTION}

The ability to directly visualize the colonic mucosa and excise polyps and localized cancers make colonoscopy the preferred screening test and an essential tool in colorectal cancer (CRC) diagnosis. Colonoscopy is important in the detection of anastomotic recurrence, synchronous and metachronous cancer in patients submitted to surgery for CRC and is mandatory in a surveillance program ${ }^{(3)}$.

Carcinoembryonic antigen (CEA) is an oncofetal protein that is raised in the serum of patients with a variety of cancers, namely CRC. It has a low sensitivity and specificity for diagnosis and, therefore, should not be used as a screening tool. However, in patients with newly diagnosed CRC, the absolute level of the serum CEA correlates with disease burden and has prognostic value. Furthermore, after surgical resection the persistence of elevated CEA levels implies the presence of residual disease and, as a surveillance tool, CEA has a significant sensitivity. Therefore, current guidelines recommend that CEA should be evaluated at diagnosis, before and after surgery and during surveillance of $\mathrm{CRC}^{(2)}$.

In a patient with personal history of $\mathrm{CRC}$, a false-positive CEA elevation results in multiples and expensive exams and in a high patient anxiety level. Turner and coll. found that bowel cleansing was associated with increased CEA levels, suggesting a need for timing the surveillance colonoscopy and collection of blood samples ${ }^{(5)}$. Furthermore, the rise was particularly marked in high risk patients for CRC. Our aim was to evaluate how important is the influence of bowel preparation and/or colonoscopy in CEA blood levels.

\section{CASES}

We included 37 consecutive persons that underwent routine colonoscopy in our Department. Indications for colonoscopy were: colonic adenoma surveillance, surveillance after CRC resection, symptoms (diarrhea, constipation and anemia), familial CRC risk, standard risk surveillance and endoscopic treatment.

Exclusion criteria were the following: (i) patients under chemotherapy; (ii) patients with inflammatory bowel disease, diabetes, chronic obstructive pulmonary disease, active ulcerative peptic disease, diverticulitis, chronic liver disease or recent abdominal surgery; and (iii) in-patients.

\footnotetext{
Declared conflict of interest of all authors: none

1 Departamento de Gastroenterologia; ${ }^{2}$ Departamento de Patologia Clinica, Hospital Garcia de Orta, Almada, Portugal; ${ }^{3}$ Departmento de Matemática e Centro de Matemática e Aplicações - CEMAT, Instituto Superior Técnico, Universidade de Lisboa, Lisboa, Portugal.

Correspondence: Rita G. Sousa. Rua Fernando Calhau n`9, Aroeira, 2820-128 - Charneca de Caparica, Portugal. E-mail: ritagsousa@gmail.com
} 


\section{METHODS}

The study protocol was approved by the Hospital Ethics Committee in agreement with national legal requirements.

After informed consent, blood samples were collected (1) 5-7 days before bowel cleaning, (2) before colonoscopy and (3) immediately after colonoscopy.

Colonoscopies were performed by different endoscopists in our Endoscopy Unit, where blood samples were also taken. The information gathered included indication for colonoscopy, type of bowel cleaning, colonoscopy duration, intervention during the procedure (biopsy, polyp resection, clips application), medications used for sedation and exam difficulty, as perceived by the operator. If tissue samples were collected, information from the pathology report was later added.

CEA levels were determined by electrochemiluminescence by the "Sandwich" immunoassay (E170 Roche Diagnostics). The upper limit of normal value was $3.5 \mathrm{ng} / \mathrm{mL}$ for nonsmokers and $7 \mathrm{ng} / \mathrm{mL}$ for smokers. The statistical methods used were the paired t-test and ANOVA.

The patients with raised CEA levels from the baseline values (Group A) were compared with the patients with stable or reduced CEA levels (Group B).

\section{RESULTS}

Of the 37 patients included, 22 were male and 15 female. The age range was 28-84 with a mean of 56 years. The information regarding colonoscopies is presented in table 1 . The main indications for colonoscopy were symptom investigation and colonic adenoma surveillance in 30\% patients each. Ninety-two percent of the patients used polyethylene glycol for bowel cleansing. Fifty-one percent of colonoscopies took less than 20 minutes and $41 \%$ between 20 and 40 minutes.

TABLE 1. Information concerning colonoscopy

\begin{tabular}{ll}
\hline Indication for colonoscopy & $\%$ \\
Adenoma surveillance & 30 \\
Surveillance after CRC resection & 16 \\
Symptoms (diarrhea, constipation and anemia) & 30 \\
Familial CRC risk & 14 \\
Standard risk surveillance & 3 \\
Endoscopic therapy & 8 \\
Colonoscopy duration & \\
Less than 20 minutes & 51 \\
Between 20 and 40 minutes & 41 \\
More than 40 minutes & 8 \\
Intervention & \\
Biopsies & 38 \\
Polypectomy & 16 \\
Clips & 3 \\
No intervention & 43 \\
Colonoscopy difficulty & \\
Easy & 43 \\
Moderate & 43 \\
Difficult & 14 \\
\hline
\end{tabular}

CRC: colorectal cancer
Fifty-seven percent of colonoscopies included intervention, namely biopsies (in 14 patients), polypectomy or clip application. Histology disclosed low-grade dysplasia in six patients, unspecific inflammatory alterations in three patients and normal mucosa in five patients. Six polypectomy were performed, allowing the removal of five low-grade adenomas and one high-grade adenoma. Forty-three percent of colonoscopies were easy or of moderate difficulty. All colonoscopies were performed with the patient under conscious sedation.

Mean CEA levels were 1.9, 2 and 1.8 for (1), (2) and (3), with standard deviations $0.22,0.23$ and 0.21 , respectively. An increase in (2) value comparing with (1) was observed in 20/37 patients $(P=0.018$; Figure 1$)$, whereas $17 / 37$ revealed unchanged or reduced CEA levels (Groups A and B, respectively). Group A patients had a mean age of 54 years as Group B patients had a mean age of 59 years. 13/20 in Group A patients had endoluminal interventions, namely 10 biopsies (three normal mucosa, four low-grade dysplasia and three inflammatory alterations) and three polypectomies (two low-grade adenoma and one high grade adenoma). In Group B 8/17 patient had interventions, namely four biopsies (two normal mucosa and two low-grade dysplasia), three polypectomies (low-grade adenoma) and one clip application. Seventeen patients (eight in Group A and nine in Group B) had a history of previous adenomatous polyps or colorectal cancer.

In 29/37 patients, CEA value decreased from (2) to (3) $\left(P=1.3 \times 10^{-7} ;\right.$ Figure 2$)$. No significant differences were found between (1) and (3).

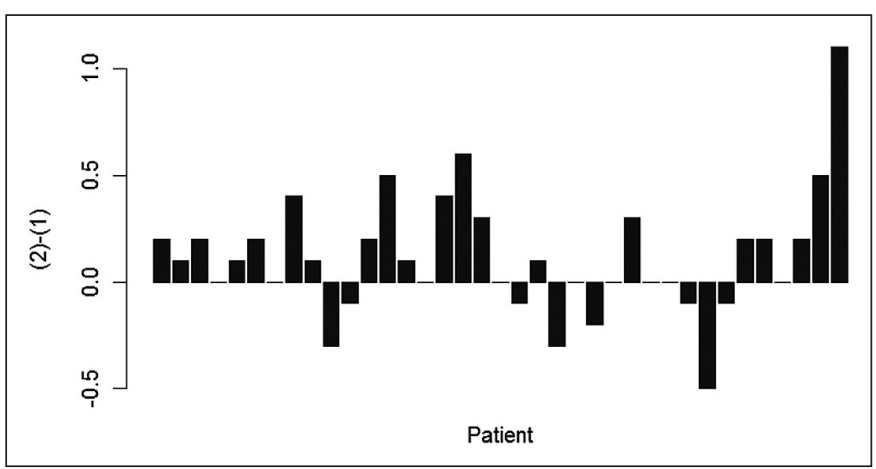

FIGURE 1. Carcinoembryonic antigen levels variation between baseline (1) and pre-colonoscopy (2)

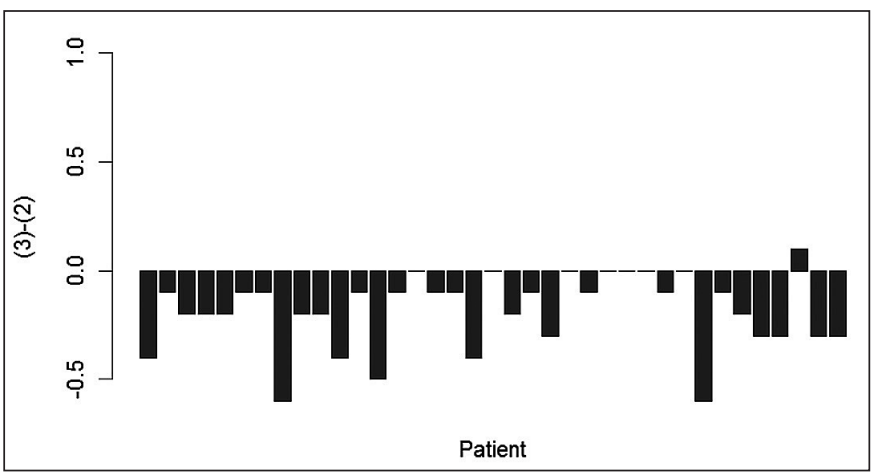

FIGURE 2. Carcinoembryonic antigen levels variation before (2) and after (3) colonoscopy 
The differences found were unrelated to colonoscopy indication, type of bowel cleansing, colonoscopy duration, endoluminal procedures, exam difficulty or sedation.

All CEA values were below the upper normal limit, except in one patient. Assay imprecision (coefficient of variation - CV) was assessed by use of commercial quality-control materials, PreciControl Tumor Marker (Roche, Diagnostics). The overall $\mathrm{CV}$ was calculated by use of each concentration of the control material in a daily run, for different lots of reagents and calibrations during the test period (Table 2).

TABLE 2. Summary of imprecision data for commercial quality-control materials

\begin{tabular}{lcc}
\hline Control Material & Mean CEA $(\mathrm{ng} / \mathrm{mL})$ & CV $(\%)$ \\
\cline { 3 - 4 } PreciControl Tumor Marker Level 1 & 3.94 & 3.8 \\
PreciControl Tumor Marker Level 2 & 43.31 & 3.43 \\
\hline
\end{tabular}

CEA: carcinoembryonic antigen; $\mathrm{CV}$ : coefficient of variation

\section{DISCUSSION}

Colonoscopy and tumor markers are important tools in the follow-up of patients after surgery for CCR, so their evaluation may be performed at the same time in a given patient at regular intervals. False-positive CEA elevations are known to be related to inflammatory bowel disease, diabetes, chronic obstructive pulmonary disease, active ulcerative peptic disease, diverticulitis and chronic liver disease. It seemed pertinent to assess if colonoscopy could be associated with changes in CEA blood levels.

With the same concern, Çetinkaya and collaborators measured serum prostatic specific antigen (PSA) before colonoscopy, immediately after laxative enema, at 24-48th hour, the 7th and the 14th day after colonoscopy in 44 patients and verified that PSA was elevated after laxative enema, at 24-48th hour and the 7th day from the baseline and had subsequently declined by the 14th day ${ }^{(1)}$. The PSA levels were significantly higher in patients with larger prostate volume, which suggested that the PSA is released by prostate manipulations.

Turner and collaborators measured CEA levels in 20 patients before, immediately and at least 14 days after colonoscopy. 11/20 patients had CEA levels peri-colonoscopy higher than baseline level and all patients with polyps and/ or previous CCR (5/20) had significantly higher CEA levels than those without polyps $(P<0.006)$. Authors proposed to take into account the timing of cleansing procedures and the CEA measurement and suggested that the CEA meas- urement after bowel preparation should be used to identify a subgroup of patients who had a higher risk for CCR and therefore should be monitored more closely. However this study was limited by the reduced number of patients enrolled. In addition, bowel cleansing was done using cleaning enemas, which may have a more pronounced mechanical action on the colonic mucosa, possibly contributing to a higher release of CEA into the blood.

But later So and colleagues replicated the Turner study in 24 patients and found no relationship between serum CEA levels and bowel preparation as well as no CEA rise after colonoscopy in high-risk patients ${ }^{(4)}$.

Our study includes a larger sample of patients, more precisely 37 patients. We found an increase of CEA levels with bowel cleansing $(P=0.018)$, an effect which was lost with colonoscopy, since there was no significant difference between (1) and (3). CEA increase occurred mainly in younger patients and in patients with more endoluminal intervention.

All CEA values were below normal limit, except in one patient. This patient was a 52 year-old female who had all CEA above the upper limit of normal values. She was already under investigation for that reason and until the present no cancer has been diagnosed. Like the majority of patients, she had a CEA increase between (1) and (2) and a decrease between (2) and (3).

CEA elevation after bowel cleansing is assumed to result from the release of CEA from unstable cells of the colonic mucosa into the blood stream in answer to colonic purgation, which is consistent with the presence of more lesions and the need to perform polypectomy/biopsy ${ }^{(5)}$. The bowel cleansing results in dehydration, factor that wasn't considered in our study and that could result in CEA elevation.

However, all CEA values were below the normal limit, therefore without clinical significance.

\section{CONCLUSIONS}

Bowel cleansing and colonoscopy apparently do not result in clinical significant CEA blood level elevation. However, a wider study could be considered to evaluate if they result in any impact whatsoever.

\section{ACKNOWLEDGEMENTS}

The authors would like to thank the Gastroenterologists and the Nurses of the Endoscopic Unit in Hospital Garcia de Orta in Almada, Portugal, who contributed to this study. 
Sousa RG, Nunes A, Meira T, Carreira O, Pires AM, Freitas J. Colonoscopia e variações do antigénio carcinoembrionário. Arq Gastroenterol. 2014,51(1):69-72.

RESUMO - Contexto - A colonoscopia é essencial para a detecção de cancer síncronos e metacronos. O antígeno carcinoembrionário é um marcador de tumor de câncer colorretal, importante como ferramenta para acompanhamento de pacientes com câncer colorretal prévio. A elevação do antígeno carcinoembrionário e resultados falso-positivos geram múltiplos exames e ansiedade no paciente. Na literatura, há referência a aumento transitório do antígeno carcinoembrionico após colonoscopia. Objetivo - Avaliar a influência da preparação intestinal e da colonoscopia nos níveis do antígeno carcinoembrionico no sangue. Métodos - Foram estudados prospectivamente indivíduos submetidos a colonoscopia de rotina em nossa instituição. Foram colhidas amostras de sangue (1) antes de limpeza do intestino, (2) antes de colonoscopia e (3) imediatamente após a colonoscopia. Níveis de antígeno carcinoembrionico no sangue foram determinados por imunoensaio técnica de "sandwich". Os métodos estatísticos utilizados foram o teste $t$ pareado e ANOVA. Resultados - Trinta e sete pacientes (22m/15f) foram incluídos; intervalo de idade entre 28-84 anos (média de 56 anos). Valores médios de antígeno carcinoembrionário foram 1,9, 2 e 1,8 para as situações (1), (2) e (3), respectivamente. Observou-se um aumento no valor (2) comparado com (1) em 20/37 pacientes $(P=0,018)$, principalmente em pacientes mais jovens e em pacientes que necessitaram de mais intervenções endoluminais. Em 29/37 pacientes, o valor do antígeno carcinoembrionário diminuiu nas situações (2) para (3) $(P=1.3 \times 10-7)$. Conclusão - Observou-se uma tendência para o aumento do antígeno de carcinoembrionico depois a limpeza do intestino, especialmente em pacientes mais jovens e em pacientes com mais intervenções endoluminais, mas sem significado clínico.

DESCRITORES - Colonoscopia, métodos. Antígeno carcinoembrionário. Neoplasias colorretais.

\section{REFERENCES}

1. Çetinkaya Z., Sezikli M., Guzelbulut F, Sezikli H, Ozçaglayan A, Sengör F, Ince AT, Kurdas OO. Serum levels of Prostate Specific Antigen are elevated after colonoscopy. Tohoku J Exp Med. 2010;222:183-6.

2. Locker GY, Hamilton S, Harris J, Jessup JM, Kemeny N, Macdonald JS, Somerfield MR, Hayes DF, Bast RC Jr; ASCO. ASCO 2006 update of recommendations for the use of tumor markers in gastrointestinal cancer. J Clin Oncol. 2006;24:5313.
3. Rex DK, Johnson DA, Anderson JC, Schoenfeld PS, Burke CA, Inadomi JM. American College of Gastroenterology guidelines for colorectal cancer screening 2009. Am J Gastroenterol. 2009;104:739.

4. So JB, Alexander DJ, Chia YW, Ngoi SS, Lee L, Goh PM. A study of the effects of bowel preparation on CEA levels in patients undergoing surveillance colonoscopy. J R Coll Surg Edinb. 1997;42:105-6.

5. Turner J, Sturgeon C. Effect of bowel cleansing and colonoscopy on serum CEA levels. J R Coll Surg Edinb. 1993;38:89-91. 